\section{Organizational identification among Brazilian public employees: a study of the cultural sector}

\author{
Flávia de Souza Costa Neves Cavazotte \\ Pontifical Catholic University of Rio de Janeiro (PUC-Rio), \\ IAG Business School, Department of Management, Rio de Janeiro, Brazil \\ Fábio Francisco de Araujo \\ Federal University of Rio de Janeiro (UFRJ), Health and Science Center, \\ Josué de Castro Institute of Nutrition, Rio de Janeiro, Brazil
}

\section{Ana Lúcia de Abreu}

Instituto Brasileiro de Mercado de Capitais (IBMEC), Management College, Rio de Janeiro, Brazil
Received on

07/11/2016

Approved on

01/05/2017

\section{Responsible editor:}

Prof. Dr. João Maurício Gama

Boaventura

Evaluation process:

Double Blind Review

\begin{abstract}
Purpose - This study aims to understand the identification of public employees with the organizations in which they work by analyzing its determinants and consequences, in order to subsidize human resource management policies within these organizations.
\end{abstract}

Design/methodology/approach - The study is based on data collected from two federal public institutions in the cultural sector, hereby metaphorically named "Young Executive" and "Older Lady". A structured questionnaire was developed and voluntarily answered by employees from both organizations. The measurement and structural models were evaluated through structural equations, applying Partial Least Squares (PLS).

Findings - Data analysis indicates that alignment between individuals' values and the values of organizations is related to employees' organizational identification with the company. The results show that there is greater organizational identification among "Older Lady" employees, as a consequence of their greater alignment to it in comparison with "Young Executive" employees. The level of organizational identification influences employees' organizational citizenship and intention to leave these organizations.

Originality/value - The study contributes to understand organizational identification among Brazilian public company employees, presenting evidence that advance knowledge on the subject and subsidize the formulation of management policies in the sector.

Keywords - Organizational identification; value alignment; organizational citizenship; voluntary turnover.

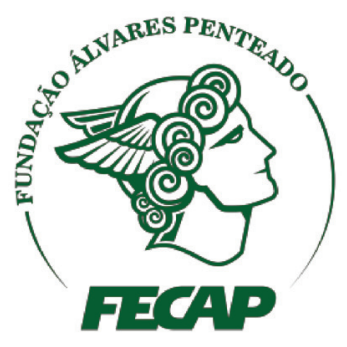

\section{Review of Business} Management

DOI: $10.7819 /$ rbgn.v19i64.3366 


\section{Introduction}

When we observe Brazilian reality, management in public companies is often described as marked by routines that are full of bureaucratic principles, of technicalism and mechanicism that predominate over more modern administrative approaches (Cavalcanti, 2005; Pires \& Macedo, 2006). This focus on formal aspects and routines has obscured the importance of the human aspects associated with the work environment, and particularly with people management in that context. However, attention to subjective elements such as the connections between employees and their organizations through the study of organizational identification, of how it occurs and how it influences individuals and public organizations (Ashforth, Harrison \& Corley, 2008) - can lead to the development of more effective policies as to performance in these organizations, by fostering the efficient accomplishment of their missions and the generation of a more positive atmosphere among employees (He \& Brown, 2013).

This study seeks to better understand the importance of organizational identification among public employees by analyzing its determinants and consequences. The main objective of the study is to analyze whether organizational identification is influenced by the alignment of employee values with those of the company ( $\mathrm{P}-\mathrm{O}$ fit), whether it influences citizenship behavior and voluntary turnover, and if it mediates the relationship between $\mathrm{P}-\mathrm{O}$ fit and employee behavior. Although organizational identification in public sector organizations has been studied in fields of executive management, such as secretaries of state (e.g. Marra, Fonseca \& Marques, 2014), and service provision, such as higher education (e.g. Santos, Vieira \& Garcia, 2013), research that seeks to empirically analyze the causes and effects of the organizational identification of public employees is rare. However, this type of analysis is important to reach a deeper understanding of how these connections are promoted and to verify their importance, and thus generate a more robust foundation to support human resource management policies in this sector.

This research contributes in this way, and advances the theoretical field by proposing that organizational identification is influenced by alignment between employee values and organizations' core values, that it is a key element bonding employees and public organizations, and that it can promote in them behavior that makes organizations more effective, specifically as to engagement in peer collaboration and intention to remain in these organizations. The propositions were investigated based on data collected from employees belonging to two public organizations from the cultural sector. In this paper, due to their characteristics and the need to protect their identities, these companies are referred to as the "Older Lady" and the "Young Executive". The results of this analysis are discussed in terms of their theoretical and practical implications, with recommendations for the management of people in Brazilian public companies.

\section{Theoretical references}

\section{I Individual identity}

Human identity is one of the most fundamental notions of what constitutes essentially "being" for ourselves and in relation to the world. Although it is constituted in people's imaginary and is created in their minds, identity has concrete consequences for individuals and is reproduced in their actions and in their discourse (Bauman, 2005). Giddens (2002) discusses the aspects of human identity as part of a lifestyle, made up of choices made by a certain actor. During the process of creating a lifestyle, there are several alternatives, and these choices are influenced by the social context. The variations in choices made by a group of actors and others simultaneously generate differentiation and exclusion processes, to the extent that these actors seek their own ontological security, that is, "a sense of continuity and permanence to the self” (Giddens, 2002, p. 223). 
The identification process is at the root of the construction of identity, for, when someone asks themselves "who am I?", that person is creating his or her identity based on what he or she recognizes and embraces as "his or hers" or as part of "himself or herself" (Bauman 2005, p.75). Thus, personal identity is formed by a continuous identification process with different elements, and is the result of constant dynamics between "being" and "becoming"; therefore, it is not predetermined, nor static in time (Jenkins, 2005).

Jenkins (2005) considers the identification process a basic mechanism that people use to distinguish themselves from each other; to him, the formation of identity occurs through systematic analysis of their similarities and differences in relation to other people and objects. In the process of individual identification, the evaluation of differences in relation to others are predominant, aiming at defining in what "I" differ from "them." With regard to collective identification, the author relates it to the similarities identified among the individuals that make up a group, in such a way that the group can be seen as a cohesive whole, expressing the idea of unity.

Other authors also reflect about identity in the postmodern age, and about its impacts on the different contexts in which individuals are immersed, among them the organizational context. Hall (2005), for example, believes that structural changes in society have led to the shifting and fragmentation of identities. According to Hall, an individual was considered a single subject that possessed a fixed identity. However, in postmodern times, scholars began to refer to the fragmentation of identity. In this way, room for the emergence of new identities was created, and they can be multifaceted and antagonistic, and manifest in individuals according to the context (Bauman, 1999).

Thus, authors have discussed the identity of an individual as unstable, mutant and, above all, dependent on how that individual belongs to each cultural system in which he or she participates. Bauman (2005), for example, presents the notion of multiple possibilities of identity, establishing a distinction between chosen identities and imposed identities. In the same sense, Ramarajan (2014) points out that identities are multiple, emphasizing that these categories of identities can be revealed in a simultaneous and conflicting way. However, to Bauman, they can coexist and reduce conflict, depending on the context and on the way in which individuals experience their multiple identities, even though, in some cases, they might express themselves in a conflicting way.

At the core of an individual's identity, a person's self-concept includes the various elements that are idiosyncratic to them, such as their interests and personal characteristics. It plays an essential role in the human interpretative structure, in how people feel and behave in the various domains of life. This self-concept is made up of the set of self-descriptions and selfassessments subjectively available to an individual (Hogg \& Abrams, 1988). Social identities, on the other hand, are associated with the groups that an individual belongs to (Hogg, 1996), as explained below.

\subsection{Social identities}

According to Tajfel's social identity theory (1972, p. 293), "a system of social categorizations creates and defines an individual's own place in society." Social identity theory advances questions regarding how individuals incorporate belonging to social groups into their identities. People tend to classify themselves and others according to various social categories, such as members of organizations, religious affiliations, by sex and age group, and others (Tajfel \& Turner, 1986). The set of social categories an individual considers him or herself to belong to makes up his or her social identities (Tajfel, 1978; Tajfel \& Turner, 1986).

According to social identity theory, identification allows individuals to define themselves as members of social categories that differentiate them from each other as individuals, but also define them in terms of what they share 
with other members of the groups to which they belong. To Ashforth and Mael (1989), social categorization has two functions: one for cognitive segmentation and another for organization of the social environment. In this sense, an individual is defined by the archetype of the category in which he or she is classified (stereotypes) and by the social classification that enables him or her to be placed in the environment.

However, social identities are made up not only of representations that individuals make for themselves in their social environments, referring to the different groups to which they belong, but also by opposition groups, to which they do not belong. We can also observe that some social identities tend to be considered more positive the more an individual recognizes him or herself to be a valued person because of the group with which he or she share their social identity (Adler, 1986, Machado, 2003). The theory of social identification developed by Tajfel (1978, 1981) and Tajfel and Turner (1986) supported the later development of the organizational identification concept.

\subsection{Organizational identification}

According to Sluss and Ashforth (2007), the study of identities and identification within organizations paved the way for several reflections on how individuals define and position themselves in organizational contexts. The importance of organizational identification has been discussed by scholars since the late 1960s (Brown, 1969; Hall \& Schneider, 1972; Kriekaard, 1993; Lee, 1971). However, it was in the 1980s that the concept was consolidated by propositions presented by Ashforth and Mael (1996), based on the social identity theory (Tajfel, 1978; Tajfel \& Turner, 1986).

Organizational identification can be understood as a specific form of social identification (Ashforth \& Mael, 1989), and emerges due to individuals' need to be in the world, to belong to groups in a relational and comparative way, as described in the previous section. Organizational identification may be one of the most important processes that connect employees to organizations (Araujo \& Melo, 2015; Araujo \& Tomei, 2013; Brown, 1969; Miscenko \& Day, 2015; Rotondi, 1975), and, according to Pratt (1998), is also be an important element in individuals' self-definition.

The feeling of self-defining unity and belongingness fostered by identification with an organization comes from internalizing organizational attributes within an individual's self-concept (Ashforth \& Mael, 1989). Dutton, Dukerick, and Harquail (1994) argue that a person is strongly identified with an organization when his or her identity as a member of the organization stands out in relation to the other aspects of his or her identity. Thus, according to Mael and Ashforth (1995, p. 312), "people who identify may see themselves as personifying the organization." Pratt (1998) suggests that organizational identification occurs when an individual's beliefs about his or her organization, and the elements that define it, become selfreferenced, that is, they are incorporated into his or her self-concept and begin to define who the person is for him or herself (Pratt, 1998).

Thus, when an individual becomes identified, he or she absorbs the beliefs about the organization in his or her own identity - his or her self-concept incorporates characteristics that, to that individual, define the organization as a social group, and begin to make up what "the person is," that is, becoming part of their own "self" (Jenkins, 2005). This concept of "self" defined as a member of that group provides a basis for the effects of identification on our perceptions and attitudes. The more they are identified with the group, the more individuals' attitudes and behavior are governed by it (Davel \& Machado, 2001).

The specificities that refer to the individualorganization connection are also explored by Elsbach (1998) in the metaphor "identification as a stellar constellation.” Elsbach draws a parallel between the connections between stars and people's identification with various social groups - those that are distant from a given constellation 
cannot be included in that set of stars. Social groups or organizations cognitively distant from an individual's social identity cannot be easily incorporated into his or her identity - just as the as patterns of identification or disidentification regarding certain organizations. He suggests, then, that organizations with clear and focused identities, in other words, with strong identities, attract certain individuals and repel others, just like stars do (Elsbach, 1998).

Kreiner and Ashforth (2004), supported by the ideas of Elsbach (1998) and on her expanded identification model, suggest that individuals' connection with organizations can take on one of four different conditions: identification, disidentification, ambivalent identification, and neutral identification. According to Elsbach and Bhattacharya (2001), disidentification occurs when an individual defines him or herself as not having the same attributes or principles that he or she believes define the organization, turning it into a contrasting group. According to the authors, disidentification does not correspond only to the absence of identification, but is considered a separate and unique factor, that is, a particular psychological state of antagonism. Thus, while identification is typically a positive connection between an individual and an organization, disidentification is a typically negative disconnection between and individual regarding an organization (Kreiner \& Ashforth, 2004). Neutral identification is the absence of one or another of these two forms, and ambivalent identification is the simultaneous identification and disidentification of an individual with different aspects of the same organization.

Members of any organization can also identify with a broad set of entities belonging to it, such as organizational leaders and symbols, products, and so on (Pratt, 1998). Knippenberg and Schie (2000), based on the perspective of organizational identification as a social identity proposed by Ashforth and Mael (1989), investigated the relative importance of identification with the work group and identification with the organization. The authors note that both are associated with employee attitudes and behavior, and benefit managerial practices, since they favor greater involvement and engagement by the workforce.

It is important to highlight, as pointed out in the study by Riketta (2005), that commitment and identification with an organization are associated but independent constructs. Metaanalysis conducted by the author empirically verified that affective organizational commitment and organizational identification, although correlated, are distinct constructs, particularly when identification is assessed by metrics that emphasize a sense of belonging and unity (e.g. Ashforth \& Mael, 1989) instead of affectivity. According to Riketta, in the studies that measured organizational identification in this way, it proved to be a stronger predictor than commitment to work involvement and contextual performance.

\subsection{Building research hypotheses}

According to Weick (1995), identification is also based on individuals' specific beliefs about organizations themselves as they interact with them. To the author, identification processes are determined by aspects of organizational identity that give meaning and are congruent with individual identity. Because values form the basis of a company's modus operandi, and establish what behavior is expected within the organization, it follows that the extent of individuals' identification with a group can be affected by congruence between personal and organizational values.

Alignment between person and organization, also called P-O fit, discusses the compatibility between the fundamental characteristics of a person and those that define an organization (French, Kaplan \& Harrison, 1982). The meta-analysis of Kristof-Brown, Zimmerman and Johnson (2005) investigated in a comparative way - the relationships between person-job (PJ), person-organization (PO), person-group (PG) and person-supervisor (PS) 
with attitudes and behavior from before and after hiring. Researchers observed that even during relatively brief pre-entry encounters, attitudes and decisions are strongly influenced by various types of adjustment. Attitudes about specific aspects of the environment were more strongly related to the corresponding type of adjustment. Job satisfaction was more strongly influenced by PJ adjustment, organizational commitment by PO adjustment, satisfaction with co-workers by PG adjustment, and satisfaction with supervisors by PS adjustment. The results gave additional support to the notion that individuals have different reactions to different aspects of the work environment. Subsequent research in this field has highlighted the importance of alignment between personal values and corporate cultural values (Edwards, 2008), and several studies suggest that good alignment can bring benefits to organizations in terms of employee attitudes and behavior (e.g. Andrews, Baker, \& Hunt, 2011).

The values of a company can be perceived by individuals within the organizational context or be built by the organization itself as it recognizes the importance of assuming certain principles, favoring with employees the notion that these values are part of their organizational identity. Affinity between individual and organizational values has already been observed as one of the most influential antecedents of job satisfaction, intention to leave organization, and turnover, even more than individual and organizational values alone (Dutton et al., 1994). When interaction within a company's environment promotes similarity, shared goals, common history, and others - such as when there is great alignment between a person's principles and those of the company -, organizational identification is stimulated (Dutton et al., 1994). Thus, the congruence of values promotes the internalization of individuals' ties with organizations as an identity reference, making belonging to the organization a central element in the identity of individuals (Elsbach, 1998). Thus, the following hypothesis is proposed:
H1 - Alignment between the values of the individual and the values of the organization is positively associated with the identification of employees with the organization.

When an individual becomes a militant of an organization's beliefs and values, this degree of identification can increase effort and willingness spent in the interest of this entity, and dedication of this subject to the company's name, bringing us to the concept of organizational citizenship. Citizenship behavior corresponds to initiatives that are disassociated from function, translated into spontaneous acts that benefit the organizational system, such as offering to help colleagues, volunteering for special workrelated activities, and having initiative to suggest solutions to problems (Organ et al., 2006, Podsakoff et al., 2000, Miscenko \& Day, 2015, Knippenberg \& Schie, 2000).

Identification would favor the sense of interpersonal trust among employees, the internalization of norms and values, the quality of practices and organizational processes, the desire to remain in the organization and the willingness to cooperate with others in the work environment (Dutton et al., 1994). The affinity of individuals with organizational values seems to be associated with civic organization (Porto \& Tamayo, 2005).

According to Cable and DeRue (2002), organizational identification is related to a person's adjustments in attitudes and behavior as a result of his or her connection with the organization. As reported by the authors, this identification may lead employees to organizational citizenship behavior. Likewise, positive employee attitudes towards the company, particularly their affective bond with it, would stimulate organizational citizenship behavior (Siqueira, 2003).

Organizational citizenship is a multidimensional construct (Podsakoff, Ahearne \& MacKensie, 1997; LePine, Erez \& Johnson, 2002) which encompasses different factors, its interpersonal component being cooperative behavior, or altruism (Smith, Organ \& Near 
1983). Altruism is an important element in creating synergies within work groups (Podsakoff et al., 1997; Koys, 2001). Since it brings individuals closer to the company and promotes employee identification with it, value alignment between person and company also allegedly promotes greater cohesion among individuals who are equally identified with the organization, giving the group a sense of unity and belongingness, and therefore fostering cooperation among its members.

Thus, the following hypotheses are proposed:

H2 - Organizational identification is positively associated with organizational citizenship behavior (altruism)

H3 - Organizational identification has a mediating effect on the relationship between $P-O$ fit and organizational citizenship behavior (altruism)

After finding part of his or her identity referenced by the organization, the fate of an individual and that of a company are intertwined through the relevance of this feeling of belongingness, which gives strength and intensity to the bond between individual and organization (Ashforth and Mael 1989, Mael \& Ashforth, 1992). Thus, as belonging becomes a self-defining element to the individual, the strength of his or her identification with the company would broaden the desire to remain connected (Dutton et al., 1994). Field surveys conducted in different contexts have suggested that organizational identification reduces employees' intention to leave companies and their voluntary turnover (e.g. Cavazotte, Oliveira \& Miranda, 2010, Mael \& Ashforth, 1995; Van Dick et al. 2004). Moreover, since person-organization value fit is also associated with turnover (Kristof-Brown et al., 2005), the following hypotheses are proposed:

H4 - Organizational identification is negatively related to the employee intention to leave the organization

H5 - Organizational identification has a mediating effect on the relationship between $P$-O fit and the employee intention to leave the organization

Figure 1 synthesizes the hypotheses proposed in this study:

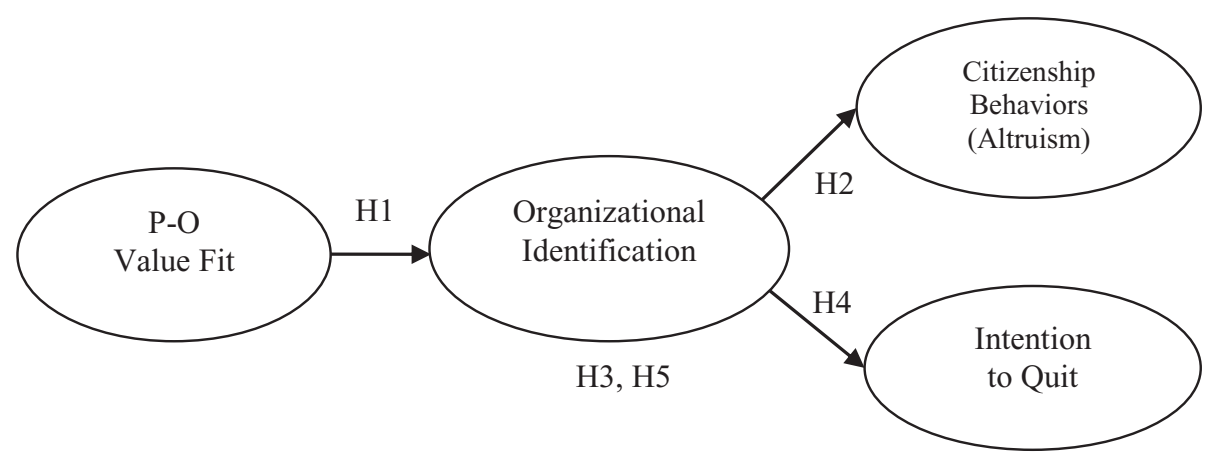

Figure 1 - Model \& Hypotheses

\section{Methodology}

This study is based on data collected from two public federal institutions in the cultural sector. The companies where the study was carried out provide a socially relevant public service that refers to the stimulation of culture in Brazil. It is noteworthy that the organizations were selected because they hold great similarities in terms of their purpose and nature, although they differ 
in the way they operate. We used metaphors to name them, first to describe and highlight their distinctive characteristics, while also concealing their identities. The metaphors also function as a resource to broaden horizons in the face of the different sets of principles and values they represent - concepts explored in this field study - and which, as seen previously, can play a central role in the formation of their institutional identities.

The first organization is responsible for providing cultural information in the different fields of human knowledge, based on Brazilian intellectual production and the most significant works of foreign culture. In a broad sense, it is a museum that brings together the production of various cultural fields. A place where memory is preserved, for written and iconographic records, it seeks to make access to information democratic. This organization is referred to in this study as the Older Lady, since it is a traditional, centennial institution that contributes to the maintenance and access to Brazil's cultural production.

The second organization under study is a regulatory agency, whose goal is to foster the production, distribution, and exhibition of works pertinent to its purpose in its various market segments. It also works to support the training of human resources, the technological development of the sector, and to ensure respect for the copyright of national and foreign works. Recently connected to the Ministry of Culture, it is referred to in this study as the Young Executive, since its structure and managerial processes are modern. It plays an important role in the growing development of the Brazilian cultural industry.

The organizations under study operate in national territory. This research was carried out with employees who work in their Rio de Janeiro divisions. During the period of this research, the Older lady had 632 employees and the Young Executive had 375, considering permanent staff (public employees in office), outsourced employees, commissioned positions and employees assigned by other agencies stationed in the mentioned cities. The Older lady's workforce shows a small increase and a strong tendency towards remaining. On the other hand, the Young Executive presents progressive growth in its workforce numbers.

\section{I Data collection}

In order to collect data, a structured questionnaire was developed, used in both organizations and voluntarily answered by employees. In addition to items on demographic data, the questionnaires included Portuguese versions of specific instruments to assess the study variables: 1) for alignment between the values of the individual and those of the organization, we used the Perceived Person-Organization Fit instrument, developed by Cable and Judge (1996), consisting of a Likert scale ranging from 1 "not at all" to " 5 " completely. An example of an item is: "Do you believe there is alignment between your values and those of [name of institution]?"; 2) Organizational identification was assessed through the scale developed by Mael and Ashforth (1992), composed of six sentences, with a scale ranging from 1 "not at all" to 7 "completely". Examples of items are "when someone criticizes my organization, it's like I am criticized" and "the success of [name of institution] feels like my personal success;" 3) Organizational citizenship was evaluated using the scale of Smith, Organ and Near (1983), which is composed of 16 items; in this study, the subscale corresponding to the altruism dimension was used, totaling seven items answered with a frequency scale ranging from 1 "never" to 7 "always". Examples are "I help co-workers with their assignments when they are absent" and "I offer suggestions to improve department work"; 4) the intention of the employees to stay in the organization was evaluated according to Mitchell, Holtom, Lee, Sablynski and Erez (2001), using three independent items, with a scale of response varying from 1 "very unlikely" to 5 "very likely". 
From the temporal perspective, research was carried out in a cross section design. A total 240 questionnaires were distributed at random: 120 among Older lady employees, or $19 \%$ of the total number of employees from that organization, and 120 among Young Executive employees, or $32 \%$ of the employees from that organization. The questionnaires were answered anonymously, and deposited by participants in an envelope sent to researchers. The response rate, $74.2 \%$ in Older lady and 70\% in Young Executive, was considered satisfactory. A single case was excluded from the 173 answers obtained, due to incomplete answers provided, thus totaling 172 valid questionnaires.

As for the profile of the participants, about half of the employees from the two companies who participated in the research work in their core field (55\% in Older lady and 50\% in Young Executive). As for their gender, 64\% of Older lady participants and $40 \%$ of the ones from the Young Executive are women. The average age of participants from the Older lady is 42 years old, and from the Young Executive, 36 years old.

\section{Analysis of results}

After receiving the questionnaires from the two organizations in which the research was undertaken, data was tabulated so that statistical analyses could be performed. In order to investigate systematic differences among companies in the variables under study, a dummy variable was created corresponding to the company to which an employee belongs, taking on value "1" for Older lady employees and "0" for Young Executive employees. This variable was included as an exogenous factor in the analyzed model. Gender (“1” female, “0” male), age, period of employment time at the company and educational level of employees were also assessed, and all used as control variables in the study, in order for their effects to be considered when analyzing the relationships between the variables in the model. Table 1 presents the Pearson correlations between the variables of interest in the study.

Table 1

\section{Correlations between variables}

\begin{tabular}{|c|c|c|c|c|c|c|c|}
\hline \multirow[b]{2}{*}{ Variables } & \multicolumn{7}{|c|}{ Correlations $^{a}$} \\
\hline & 1 & 2 & 3 & 4 & 5 & 6 & 7 \\
\hline \multicolumn{8}{|l|}{1 - Company ${ }^{\mathrm{b}}$} \\
\hline $2-$ Gender $^{\mathrm{c}}$ & $0.18^{*}$ & & & & & & \\
\hline $3-$ Age & $0.29^{* *}$ & -0.01 & & & & & \\
\hline 4 - Education & -0.05 & 0.09 & $0.28^{* *}$ & & & & \\
\hline 5 - Organizational identification & $0.19^{*}$ & 0.13 & $0.18^{*}$ & 0.00 & & & \\
\hline $6-\mathrm{P}-\mathrm{O}$ value fit & $0.16^{*}$ & 0.09 & 0.12 & -0.01 & $0.46^{* *}$ & & \\
\hline 7 - Intention to quit & $-0.16^{*}$ & -0.04 & $-0.21^{* *}$ & -0.01 & $-0.39^{* *}$ & $-0.29^{* *}$ & \\
\hline 8 - Organizational cit.: altruism & 0.11 & 0.12 & $0.28^{* *}$ & $0.23^{* *}$ & $0.27^{* *}$ & $0.25^{* *}$ & -0.12 \\
\hline
\end{tabular}

Note: $\mathrm{N}=172$

${ }^{a}$ Correlation is significative* $\mathrm{p}<0,05 \mathrm{e}^{* *} \mathrm{p}<0,01$ (two-tailed)

${ }^{\mathrm{b}}$ Older lady= 1 Young Executive $=0$

${ }^{\mathrm{c}}$ Female $=1$ Male $=0$ 
Subsequent analyses were performed using the PLS estimation (Partial Least Squares). In this type of structural equation modeling, the measurement model is evaluated by means of a Confirmatory Factor Analysis (CFA) according to the method of Wetzels, Odekerken-Schröder and van Oppen (2009). The results were analyzed in terms of their adherence to the criteria of convergent and discriminant validity proposed by Chin (2010): large and significant loadings of the variables observed in their respective latent variables, and small loadings in the other variables;
Average Variance Extracted (AVE) values that are equal to or greater than 0.50; Composite Reliability (CR) values that are equal to or greater than 0.70; and the square root of the AVE of a latent variable that is greater than the correlations of this variable with the others.

The results of the confirmatory analyses indicated that the study measurement model had adequate convergent and discriminant validities. Table 2 presents the results of data analysis at this step.

Table 2

\section{Results: measurement model}

\begin{tabular}{|c|c|c|c|c|c|c|c|}
\hline Latent variables & Loadings & Avg. & S.D. & GPA & AVE & $a_{C}$ & $\begin{array}{c}\text { Highest } \\
\text { correlation }^{\mathrm{a}}\end{array}$ \\
\hline P-O Value Fit (VF) & $0.77-0.88$ & 3.17 & 1.00 & 0.88 & 0.70 & 0.79 & 0.48 \\
\hline Organizational Identification (ID) & $0.72-0.86$ & 5.23 & 1.53 & 0.92 & 0.66 & 0.89 & 0.48 \\
\hline $\begin{array}{l}\text { Organizational Citizenship - } \\
\text { Altruism (OCB) }\end{array}$ & $0.60-0.81$ & 5.58 & 0.81 & 0.82 & 0.55 & 0.71 & 0.30 \\
\hline Intention to Quit (IQ) & $0.96-0.97$ & 2.25 & 1.21 & 0.98 & 0.93 & 0.96 & 0.30 \\
\hline
\end{tabular}

${ }^{a}$ Highest correlation (absolute value) to the other latent variables.

Since the data used in the analysis of the hypotheses under study were collected using the same method and same source of information, Common Method Variance (CMV) in the sample was evaluated. The results of the Harman test (Malhotra, Kim, \& Patil, 2006; Podsakoff \& Organ, 1986) indicated the presence of five clearly distinct factors according to the simple structure in the pattern matrix (alignment, identification, altruism-individuals, altruism-organization, and intention to quit), which together explained 70\% of the variance in the sample. Since the factor with the highest eigenvalue (identification) explained only $32 \%$ of the variance (less than $50 \%$ of the total variance), we can conclude that CMV is unlikely to have substantially biased the observed results.

The subsequent analysis sought to evaluate the quality of the theoretical model under test, by checking the significance of the coefficients observed in the equations corresponding to the structural model and the explained variance ratio (R2) for the endogenous latent variables (Chin, 2010, Hair, 2012, Urbach \& Ahlemann, 2010). The statistical significance of the estimated coefficients was evaluated using the bootstrapping technique, with the sample equal to 172 and the number of resamplings equal to 500 . Figure 2 presents the results obtained in the analysis of the hypotheses of the study. 


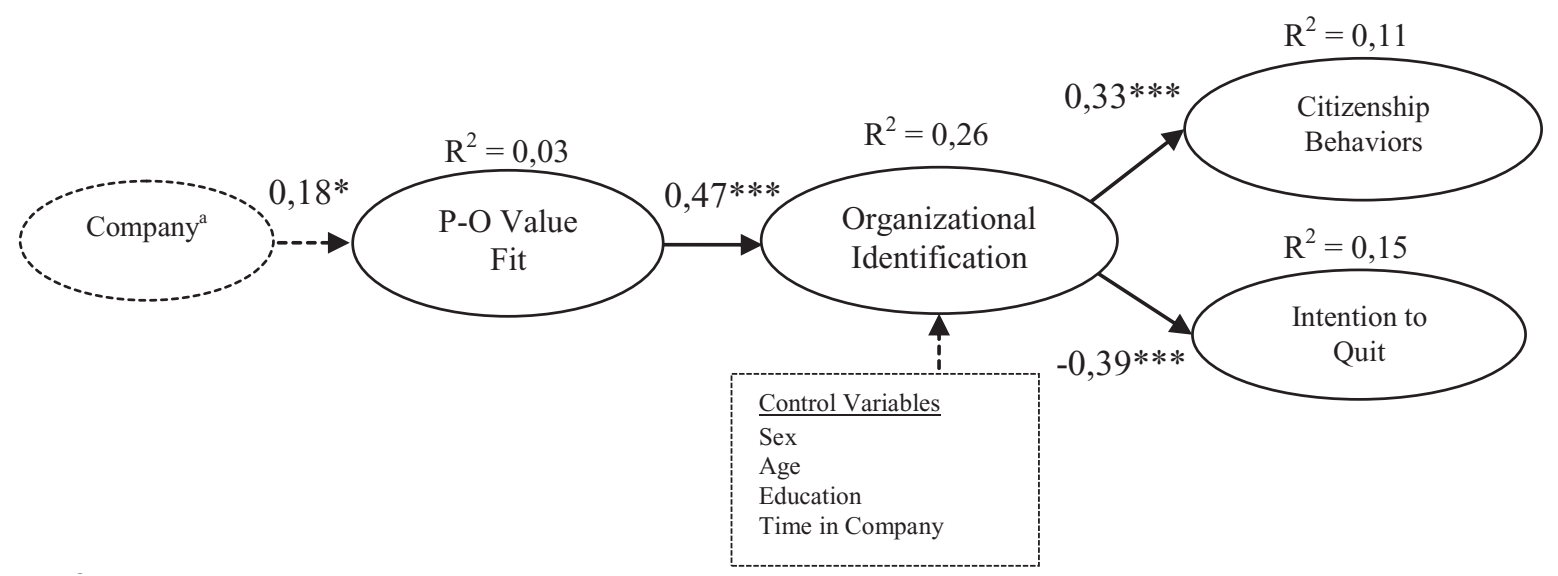

Figure 2 - Results: structural model

Note: ${ }^{\mathrm{a}}$ Older lady $=1$ Young Executive $=0$

${ }^{* * *} \mathrm{p}<0.001,{ }^{* *} \mathrm{p}<0.01,{ }^{*} \mathrm{p}<0.05$

The model explained $26 \%$ of the variance of the latent variable of central interest, organizational identification, presenting an $\mathrm{R}^{2}$ of 0.26. The dummy variable Company, which would indicate whether the respondent is an Older lady or Young Executive public employee, had a positive and statistically significant effect on the alignment of individual-organization values $\left(\beta_{\text {Company-VF }}=0.18, \mathrm{p}<0.05\right)$. Therefore, we observed that Older lady's employees tend to present greater value alignment with their company than those from Young Executive. We also observed that there was an indirect effect of the Company variable on organizational identification mediated by $\mathrm{P}-\mathrm{O}$ value fit, also statistically significant $\left(\beta_{\text {Company-VF-ID }}=0.08, \mathrm{p}<0.05\right)$. This result indicates that there is greater organizational identification among Older lady employees, and that this difference is associated with the greater alignment of individual-organization values in that group.

As expected, the $\mathrm{P}-\mathrm{O}$ value fit had a positive and statistically significant effect on organizational identification $\left(\beta_{\mathrm{VF}-\mathrm{ID}}=0.47 ; \mathrm{p}<0.001\right)$, giving empirical support for H1. Organizational identification had a direct and positive influence on organizational citizenship behavior (altruism) and on employees' intention to quit (transfer). The estimated effect of identification on altruism was positive and statistically significant $\left(\beta_{\text {ID-OCB }}=0.33, \mathrm{p}<0.001\right)$, and the estimated effect of identification on the intention to transfer was negative and statistically significant $\left(\beta_{\text {ID-IQ }}=-0.39 ; \mathrm{p}<0.001\right)$. Thus, we conclude that the hypotheses $\mathrm{H} 2$ and $\mathrm{H} 4$ obtained empirical support in the study. The value alignment also had similar and significant indirect effects on the variables organizational citizenship and intention to quit $\left(\beta_{\mathrm{VF-ID-OCB}}=0.15 ; \beta_{\mathrm{VF-ID-IQ}}=-0.17\right.$; $\mathrm{p}<0.001)$, thus confirming the hypotheses $\mathrm{H} 3$ and H5. We observed, therefore, that the effect of $\mathrm{P}-\mathrm{O}$ value alignment on the behavior of interest occur through the greater organizational identification of the employees with their respective companies.

It is also worth noting that positive direct effects of company time on organizational identification $\left(\beta_{\text {Time-ID }}=0.15, \mathrm{p}<0.05\right)$ were observed, and negative indirect effects of company time on the intention to quit, intermediated by the identification Organizational $\left(\beta_{\text {Time-ID-IQ }}=-0.06, \mathrm{p}<0.05\right)$. We concluded, therefore, that the bond time with the company is associated with the greater identification of the employee with it, and consequently with their intention to remain in it. 


\section{Discussion}

The results of this study allow us to affirm that the identification of public employees with companies in the cultural sector is a relevant element associated with their attitudes and behavior at work. The study presents evidence that alignment between the values of these individuals and those of their organizations is associated with their greater identification with these companies, and that organizational identification is positively associated with cooperative behavior and negatively associated with employees' intention to quit the organizations.

Literature on identification is diverse and extensive. We should note that the different attempts to clarify this phenomenon reach formulations that range from its diverse foci to its different antecedents and consequents. The findings of this study are in line with perspectives that emphasize the importance of organizational identification as a central element in creating bonds between individuals and companies and as a driving force of their work efforts (Andrews, Baker \& \& Hunt, 2011; Dutton et al. 1994, Miscenko \& Day, 2015, Knippenberg \& Schie, 2000, Kristof-Brown, Zimmerman \& Johnson, 2005, Weick, 1995). The subjectively constructed understandings of individuals about who they are and who they want to become inside and outside organizations seem to be involved in and are important to making sense of their behavior.

Data analysis indicates that an individual's value alignment with the values of an organization is associated with his or her identification with the organization. The results reveal that there is greater organizational identification among Older lady employees, as a result of the greater fit between individual values and the values of the federal organizations in which employees work. In addition, the results reveal that organizational identification has a direct influence on altruism among these civil servants, one of the dimensions of organizational citizenship with the greatest impact on work group performance. Identification is also inversely related to the employees' intention to leave the company, which is reduced when they incorporate their belongingness to the public organization into their identity. The findings observed in this research also corroborate and expand the results of Cable and DeRue's study (2002) on the importance of the adjustment of person-organization at the root of employees' attitudes and behavior that can favor companies.

We observed that, although the two public organizations under study have the same nature and relatively similar missions, they differ in terms of the scope of their roles (Older lady more focused on preservation and cultural dissemination and Young Executive on control and cultural development), their maturity (greater in Older lady), and their management structure (more professional in Young Executive), which led us to compare them in this investigation. These and other differences give rise to the formation of relatively distinct organizational values in the two companies. The results of this study indicate that there is greater value alignment between the Older lady's employees than the Young Executive's, and that this alignment explains part of the differences observed in the level of organizational identification and outcome behavior of the civil servants studied.

Also, in this study the analysis of the relationship between organizational identification and employee attitudes and intentions considered the effect of the company they are assigned to (Older lady or Young Executive), as well as the period of employment with the company, age, gender and level of education. Thus, it can be said that the observed results represent the incremental contribution of organizational identification to the attitudes and behavior analyzed, above and beyond differences that may exist between the two studied organizations and demographic factors. Therefore, as shown in the structural analysis, it is important to emphasize that, although $\mathrm{P}-\mathrm{O}$ fit and identification are stronger among the employees of one of the companies, the influence of these factors on employee attitudes and behavior is independent of the company in which they 
operate, that is, despite the differences observed between the companies, value alignment and consequent identification are relevant antecedents of the behavior studied for the employees of the two organizations.

\section{Conclusion}

As noted by Giddens (2002), the process of identity establishment takes place through an individual's personal choices and decisions, which are reflected in all the social contexts of which he or she participates. The observations of this research reflect what was proposed by Scott and Lane (2000), that is, that organizational identification intensifies to the extent that there is greater alignment between the values of the individual and those of the organization itself. This finding reinforces the notion that value fit strengthens personal identity and gives greater ontological integrity and security to individuals, thus favoring organizational identification.

Stronger organizational identification has been found to be associated with more effort by employees to cooperate with each other and with the public organization they serve, and with their intention to remain in these organizations (Dutton et al., 1994). In this sense, when considered in human resource management processes, the phenomenon of identification can contribute to the more effective management of employees in Brazilian public companies. Since identification is associated with the sense of adherence and introjection of organizational goals, being a product of the social bonds between individuals and these organizations (Vanderberg et al., 1994), it seems to deserve more attention by management in other public organizations, from this and other segments.

When the consequences of organizational identification are analyzed, we see that it seems to play an important role as a booster of citizen behavior, and is therefore relevant in the formation of a strong awareness of the role that these servers have to play, required for the maintenance of a service geared to the needs of the population. Still referring to the consequences of identification, the investigation confirmed its inverted relationship with employees' intention to leave the organization, indicating its importance for the management of turnover in public companies.

This study, however, has some limitations, such as the lack of a more subjective analysis of the identification processes, which would allow to establish which specific characteristics or values of each organization are relevant to the greater or lesser fit with their employees. In addition, the value alignment measure encompasses three general items and the data was collected from only two companies, which restricts specific discussions about the nature of the values behind the effects and the generalization of the observations to other companies. Therefore, we suggest that future studies be carried out to better clarify how organizational identification develops or changes over the duration of employees' connection with their companies, recommending special attention to the institutionalization of organizational values and the investigation of specific values as determinants of alignment and/ or greater identification among public employees. We observed that the operationalization of citizenship focused only on altruism, a fact that deters the generalization of findings for the other dimensions of citizenship. In this way, this aspect can be considered a limitation that opens the way for other analyses of the citizenship construct in future research. The transversal character of the study is also considered a limiting factor. Carrying out longitudinal studies could favor the verification of causal associations between alignment, organizational identification, and consequent attitudes and behavior of employees.

We suggest that future studies also investigate the effects of identification on the formal performance of public employees and their work areas, as well as on the quality of the service as perceived by clients in these sectors. In addition, while attempting to expand possible study themes related to identification, future studies 
could evaluate organizational identification as a moderating variable in relation to employees' involvement, engagement, or citizenship in both public and private companies, as suggested in the study by Tavares et al. (2016). Still reflecting on the perspective of public management, a proposal for a future study would be to evaluate how the sense of justice and specific human resource policies in public companies influence organizational identification - elements already pointed out in the literature as potential factors in the strengthening and weakening of bonds and belongingness within these companies. The evaluation of how these phenomena unfold over time and throughout the interactions and experiences lived by employees in these organizations also deserves to be emphasized, to allow a more global and dynamic understanding of the connections between Brazilian employees and public companies, and to advance knowledge about the identification phenomenon and its impact in the organizational context. Finally, we recommend that complementary investigations be carried out to explore the implications of organizational disidentification and misalignment of values in public settings governed by more or less rigid norms, and with varied levels of bureaucracy and employee participation in decision-making.

\section{References}

Adler, N.J. (1986). International dimensions of organizational behavior. Boston: Kent.

Andrews, M.C., Baker, T., \& Hunt, T.G. (2011). Values and person-organization fit: Does moral intensity strengthen outcomes? Leadership \& Organization Development Journal, 32(1), 5-19.

Araujo, F.F., \& Melo, M.A.C. (2015). Fatores de eficácia de aprendizagem organizacional na implementação da mudança: Proposta de um instrumento de análise. FACEF Pesquisa, 18(3), 209-227.
Araujo, F.F., \& Tomei, P.A. (2013). Labour relations and globalisation: An analysis of ethical dilemmas from "Le Couperet". Work, Organisation, Labour \& Globalisation, 7(1), 106-123.

Ashforth, B. E., Harrison, S. H., \& Corley, K. G. (2008). Identification in organizations: An examination of four fundamental questions. Journal of Management, 34(3), 325-374.

Ashforth, B. E., \& Mael, F. (1989). Social identity theory and the organization. Academy of Management Review, 14(1), 20-39.

Ashforth, B. E., \& Mael, F. (1996). Organizational identity and strategy as a context for the individual. In J. A. C. Baum \& J. E. Dutton (Eds.), Advances in strategic management (pp. 19-64). Greenwich, CT: JAI Press.

Bauman, Z. (1999). Modernidade e ambivalência. Rio de Janeiro: Jorge Zahar.

Bauman, Z. (2005). Identidade: Entrevista concedida a Benedetto Vecchi. Rio de Janeiro: Jorge Zahar.

Brown, M. E. (1969). Identification and some conditions of organizational involvement. Administrative Science Quarterly, 14(1), 346-355.

Cable D. M., \& DeRue, D.S. (2002). The convergent and discriminant validity of subjective fit perceptions. Journal of Applied Psychology, 87(5), 875-884.

Cable, D. M., \& Judge, T. A. (1996). Personorganization fit, job choice decisions, and organizational entry. Organizational Behavior and Human Decision Processes, 67(3), 294311.

Cavalcanti, B. S. (2005). O gerente equalizador: Estratégias de gestão no setor público. Rio de Janeiro: Ed. FGV. 
Cavazotte, F.S.C.N., Oliveira, L.B., \& Miranda, L.C. (2010). Desigualdade de gênero no trabalho: Reflexos nas atitudes das mulheres e na sua intenção de deixar a empresa. Revista de Administração da Universidade de São Paulo, São Paulo, 45(1), 70-83.

Chin, W. W. (2010). How to write up and report PLS analyses. In V. Esposito Vinzi, W. W. Chin, J. Henseler, \& H. Wang (Eds.), Handbook of partial least squares: Concepts, methods and applications in marketing and related fields (pp. 655-690). Berlin: Springer.

Davel, E., \& Machado, H.V. (2001). A dinâmica entre liderança e identificação: Sobre a influência consentida nas organizações contemporâneas. Revista de Administração Contemporânea - RAC, 5(3), 107-126.

Dutton, J., Dukerich, J., \& Harquail, C. (1994). Organizational images and member identification. Administrative Science Quarterly, 39(2), 239-266.

Edwards, J. R. (2008). Person-environment fit in organizations: An assessment of theoretical progress. The Academy of Management Annals, 2(1), 167-230.

Elsbach, K. D. (1998). The process of social identification: With what do we identify? In D. S. Whetten, \& P. C Godfrey (Eds.), Identity in organizations: Building theory through conversations (pp. 232-237). London: Sage.

Elsbach, K.D.; \& Bhattacharya, C.B. (2001). Defining who you are by what you're not: Organization disidentification and The National Rifle Association. Organizational Science, 12(4), 393-413.

French, J. R. P., Jr., Caplan, R. D., \& Harrison, R. V. (1982). The mechanisms ofjob stress and strain. London: Wiley.
Giddens, A. (2002). Modernidade e identidade. Rio de Janeiro: Jorge Zahar Ed.

Hair, J., Sarstedt, M., Ringle, C. \& Mena, J. (2012). An assessment of the use of partial least squares structural equation modeling in marketing research. Journal of the Academy of Marketing Science, 40(3), 414-433.

Hall, D.T.; \& Schneider, B. (1972). Correlates of organizational identification as a function of career pattern and organizational type. Administrative Science Quarterly, 17(3), 340-350.

Hall, S. (2005). A identidade cultural na pósmodernidade (10a ed.). Rio de Janeiro: Guaracira Lopes Louro.

He, H., \& Brown, A.D. (2013) Organizational identity and organizational identification: A review of the literature and suggestions for future research. Group and Organization Management, 38(1), 3-35.

Hogg, M. A. (1996). Intragroup processes, group structure and social identity. In W. P. Robinson (Ed.), Social groups andidentities: Developing the legacy of Henri Tajfel (pp. 6593). Oxford: Butterworth-Heinemann.

Hogg, M. A., \& Abrams, D. (1988). Social identifications: A social psychology of intergroup relations and group processes. London \& New York: Routledge.

Jenkins, R. (2005). Social Identity. (3 ed.). London: Routledge.

Knippenberg, D., \& Schie, E. (2000). Foci and correlates of organizational identification. Journal of Occupational and Organizational Psychology, 73(2), 137-147.

Koys, D. (2001). The effects of employee satisfaction, organizational citizenship behavior, and turnover on organizational 
effectiveness: A Unit-Level Longitudinal Study. Personnel Psychology, 54(1): 101-14.

Kreiner, G.E.; \& Ashforth, B.E. (2004). Evidence toward an expanded model of organization identification. Journal of Organizational Behavior, 25(1), 1-27.

Kriekaard, J. A. (1993). City marketing management. Rotterdam: RIBES.

Kristof-Brown, A. L., Zimmerman, R. D., \& Johnson, E. C. (2005). Consequences of individuals'fit at work: A meta-analysis of person-job, person-organization, persongroup, and person-supervisor fit. Personnel Psychology, 58(2), 281-342.

Lee, S.M. (1971). An empirical analysis of organizational identification. Academy of Management Journal, 14(2), 213-226.

LePine, J. A., Erez, A., \& Johnson, D. E. (2002). The nature and dimensionality of organizational citizenship behavior: A critical review and meta-analysis. Journal of Applied Psychology, 87(1), 52-65

Machado, H.V. (2003). A identidade e o contexto organizacional: Perspectivas de análise. Revista de Administração Contemporânea $R A C$, ed. especial, 51-73.

Mael, F., \& Ashforth, B. E (1992). Alumni and their alma mater: A partial test of the reformulated model of organizational identification. Journal of Organizational Behavior, 13(1), 103-123.

Mael, F.; \& Ashforth, B.E. (1995). Loyal from day one: Biodata, organizational identification and turnover among newcomers. Personnel Psychology, 48(2), 309-332.

Malhotra, N. K., Kim, S. S., \& Patil, A. (2006). Common method variance in IS research: A comparison of alternative approaches and a reanalysis of past research. Management Science, 52(12), 1865-1883.

Marra, A. V., Fonseca, J. A, \& Marques, A. L. (2014). O processo de identificação organizacional ante a reforma administrativa: Um estudo exploratório. Revista de Administração Mackenzie, 15(1), 49-72.

Miscenko, D., \& Day, D. (2015). Identity and identification at work. Organizational Psychology Review, 6(3), 215-247

Mitchell, T. R., Holtom, B. C., Lee, T. W., Sablynski, C. J., \& Erez, M. (2001). Why people stay: Using job embeddedness to predict voluntary turnover. Academy of Management Journal, 44(1), 1102-1121.

Organ, D. W., Podsakoff, P. M., \& Mackenzie, S. B. (2006). Organizational citizenship behavior: Its nature, antecedents, and consequences. London: Sage Publications.

Pires, J.C.S.; \& Macedo, K.B. (2006). Cultura organizacional em organizaçóes públicas no Brasil. Revista Brasileira de Administração Pública, 40(1), 81-105.

Podsakoff, P. M., Ahearne, M., \& MacKenzie, S. B. (1997). Organizational citizenship behavior and the quantity and quality of work group performance. Journal of Applied Psychology, 82(2), 262-70.

Podsakoff, P.M.; Mackenzie, S.B.; Paine, J.B.; \& Bachrach, D.G. (2000). Ship behaviors: A critical review of the theoretical and empirical literature and suggestions for future research. Journal of Management, 26(3), 513-563.

Podsakoff, P. M., \& Organ, D. W. (1986). Selfreports in organizational research: Problems and prospects. Journal of Management, 12(4), 531-544.

Porto, J.B.; \& Tamayo, Á. (2005). Valores organizacionais e civismo nas organizações. 
Revista de Administração Contemporânea $R A C, 9(1), 35-52$.

Pratt, M. G. (1998). To be or not to be: Central questions in organizational identification. In D. A. Whetten, \& P. C. Godfrey (Eds.), Identity in organizations: Building theory through conversations (pp. 171-207). London: Sage.

Ramarajan, L. (2014). Past, present and future research on multiple identities: Towards an intrapersonal network approach. Academy of Management Annals, 8(1), 589-659.

Riketta, M. (2005). Organizational identification: A meta-analysis. Journal of Vocational Behavior, 66(2), 358-384.

Rotondi, T. (1975). Organizational identification: Issues and implications. Organizational Behavior and Human Performance, 13(1), 95-109.

Santos, A. A. D., Vieira, A., \& Garcia, F. C. (2013). Identificação organizacional: $\mathrm{O}$ caso dos professores de uma instituição federal de ensino. Revista Gestão \& Planejamento, 14(1), 3-17.

Scott, S.; \& Lane, V. (2000). A Stakeholder approach to organizational identity. Academy of Management Review, 25(1), 43-62.

Siqueira, M. M. (2003). Proposição e análise de um modelo para comportamentos de cidadania organizacional. Revista de Administração Contemporânea, 7 (ed. especial), 165-184.

Sluss, D. M.; \& Ashforth, B. E. (2007). Relational identity and identification: Defining ourselves through work relationships. Academy of Management Review. 32(1), 9-32.

Smith, C. A.; Organ, D. W; \& Near, J. P. (1983). Organizational citizenship behavior: Its nature and antecedents. Journal of Applied Psychology, 68(4), 653-663.
Tajfel, H. (1972). La categorisation sociale. In S. Moscovici (Ed.), Introduction a la psychologie sociale, vol. 1: 272-302. Paris: Larousse.

Tajfel, H. (1978). Differentiation between social groups: Studies in the social psychology of intergroup relations. London: Academic Press.

Tajfel, H. (1981). Social identity and intergroup relations. London: Cambridge University Press.

Tajfel, H., \& Turner, J. C. (1986). The social identity theory of intergroup behavior. In S. Worche \& L. W. Austin (Eds.), Psychology of intergroup relations (pp. 7-24). Chicago: Nelson-Hall.

Tavares, S., Van Knippenberg, D., \& Van Dick, R. (2016). Organizational identification and "currencies of exchange": Integrating social identity and social exchange perspectives. Journal of Applied Social Psychology, 46(1), 34-45.

Urbach, N., \& Ahlemann, F. (2010). Structural equation modeling in information systems research using partial least squares. Journal of Information Technology Theory and Application, 11(2), 5-40.

Van Dick, R., Christ, O., Stellmacher, J., Wagner, U., Ahlswede, O., Grubba, C., Hauptmeier, M., Höhfeld, C., Moltzen, K. \& Tissington, P. A. (2004). Should I stay or should I go? Explaining turnover intentions with organizational identification and job satisfaction. British Journal of Management, 15(4), 351-360.

Vanderberg, R. J., Self, R. M., \& Seo, J. H. (1994). A critical examination of the internalization, identification, and compliance commitment measures. Journal of Management, 2O(1), 123-140. 
Weick, K.E. (1995). Sensemaking in organizations. Thousand Oaks: Sage Publications.

Wetzels, M., Odekerken-Schroder, G., \& Van Oppen, C. (2009). Using PLS path modeling for assessing hierarchical construct models: Guidelines and empirical illustration. MIS Quartely, 33(1), 177-195.

\section{About the authors:}

1. Flávia de Souza Costa Neves Cavazotte, Phd. in Management, Virginia Commonwealth University, EUA. E-mail: flavia.cavazotte@iag.puc-rio.br

2. Fábio Francisco de Araujo, Phd. in Management, Pontifical Catholic University of Rio de Janeiro, Brazil. E-mail: fabiofdearaujo@gmail.com

3. Ana Lúcia de Abreu, MSc. in Management, Instituto Brasileiro de Mercado de Capitais, Brazil.

E-mail: anadesign@ig.com.br

\section{Note:}

A preliminary version of this article was presented on XXXVIII Encontro da ANPAD - EnANPAD 2014 (Rio de Janeiro - Brasil), held on september 14 and 17. For this version, the article had update parts.

\section{Contribution of each author:}

\begin{tabular}{lccc}
\hline Contribution & $\begin{array}{c}\text { Flávia de Souza Costa } \\
\text { Neves Cavazotte }\end{array}$ & $\begin{array}{c}\text { Fábio Francisco de } \\
\text { Araujo }\end{array}$ & $\begin{array}{c}\text { Ana Lúcia de } \\
\text { Abreu }\end{array}$ \\
\hline $\begin{array}{l}\text { 1. Definition of research problem } \\
\text { 2. Development of hypotheses or research questions } \\
\text { (empirical studies) }\end{array}$ & $\sqrt{ }$ & $\sqrt{ }$ & $\sqrt{ }$ \\
3. Development of theoretical propositions (theoretical Work) & & & \\
4. Theoretical foundation/ Literature review & $\sqrt{ }$ & \\
5. Definition of methodological procedures & $\sqrt{ }$ & $\sqrt{ }$ \\
6. Data collection & & & \\
7. Statistical analysis & $\sqrt{ }$ & \\
8. Analysis and interpretation of data & $\sqrt{ }$ & \\
9. Critical revision of the manuscript & $\sqrt{ }$ & & \\
10. Manuscript Writing & $\sqrt{ }$ & \\
\hline
\end{tabular}

